\title{
The Effect of Organizational Culture on the Quality of Accounting Information Systems
}

\author{
${ }^{\mathbf{1}}$ Nurliyani, ${ }^{\mathbf{J} J u f r i}$ Darma, ${ }^{\mathbf{2}}$ Arfan Ikhsan \\ ${ }^{1}$ Master Student in State University of Medan, Medan, Indonesia \\ ${ }^{2}$ Lecturer in State University of Medan, Medan, Indonesia \\ liyani0194@gmail.com
}

\section{Abstract}

The purpose of this study is attempt to explain, empirically test, organizational culture on the quality of accounting information systems in the Regional Organization of Medan City. The survey was conducted on 38 respondents, namely the head of finance in the agency and department. Data were collected using a questionnaire. Basic SEM variance is used for data analysis. The results showed that organizational culture had a significant effect on the quality of accounting information systems. The results can be interpreted that organizational culture has an important role to realize the quality of accounting information systems.

\section{Keywords}

Organizational Culture, Quality, Accounting

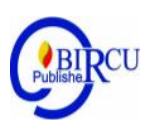

\section{Introduction}

Accounting information system is a system that collects, records, stores, and processes data to produce information (Romney and Steinbart, 2018: 36). An important part of the information system needed for decision making in organizations is the accounting information system (Samuel, 2013). Good quality information systems have several characteristics, including: reliability, integration and accessibility (Darma et al. 2018), timeliness (Ong, Day and Hsu, 2009), flexible and efficient (Stair and Reynolds, 2010: 57).

Republic of Indonesia Government Regulation No. 65 of 2010 concerning Regional Financial Information Systems (SIKD) explains that in an increasingly open state life, the government as the formulator and implementation of the APBN policy is obliged to be open and responsible for the entire results of development implementation. LGs who want to have a quality SIKD must be able to: be integrated (Satzinger, Jackson and Burd, 2009: 7) and reliability (Baltzan, 2014: 185).

Hutajulu (2017) as Secretary of Commission A of the North Sumatra Regional House of Representatives, assesses the chaotic condition of websites that are not good and not updated on the OPD resulting from the absence of special attention from the leadership of relevant agencies to keep the existence of online information facilities remain informative. Whereas the target of the regional government in 2019 will be all integrated Regional Organizations as a whole (Rajekshah, 2019).

The lack of quality accounting information systems in the Regional Apparatus Organizations is caused by organizational culture as Leidner and Kayworth (2006) say that understanding organizational culture is important for assessing information systems. Organizational culture refers to a system of shared meanings held by members that distinguishes one organization from another organization (Robbins and Judge 2013: 512). From the research results of Rapina (2014), Budi (2015) and Wisma (2015) show that 
organizational culture has a significant influence on the quality of accounting information systems.

\section{Review of Literature}

\subsection{Quality of Accounting Information Systems}

Romney and Steinbart (2018: 36) say that accounting information systems are systems that collect, record, store and process data to produce information for decision makers. Meanwhile, according to Turner, Weickgenannt and Copeland (2017: 4) Accounting information systems consist of processes, procedures, and systems that capture accounting data from business processes; record accounting data in the appropriate records; process detailed accounting data by classifying, summarizing, and combining; and report accounting data summarized to internal and external users.

Ladan, Abdullah, and Mat Saat (2017) said that the quality of the system is related to the technical efficiency of the system, regarding the consistency of the user interface, ease of use, programming errors, and system maintenance. Meanwhile according to Fitrios et al. (2018) the quality of accounting information systems is a clue that shows the ability of accounting information systems to process financial data and produce accounting information that is useful for decision makers

\subsection{Organizational Culture}

According to McShane, Glinow and Sharma (2008: 492) organizational culture is the basic pattern of shared values and assumptions that govern the way employees in an organization think and act on problems and opportunities. Organizational culture consists of values and assumptions that are shared within an organization. Whereas Robbins and Judge (2013: 512) say that organizational culture refers to a system of meaning that is understood together by members of the organization which in this case is a company so that it distinguishes between one organization and another.

According to Robbins and Judge (2013: 512) there are 7 main characteristics that reveal the essence of corporate culture, namely: Innovation and risk taking, attention to something detailed, results orientation, people orientation, team orientation, aggressiveness, and stability. Organizational culture is an important factor in information systems (Leidner and Kayworth, 2006).

Furthermore Laudon and Laudon (2012: 94) argue that to provide tangible benefits, the use of information systems must be built with a clear understanding of the organization, important factors to consider when planning a new system are as: environment, organizational structure, culture and politics, type of organization leadership style and interest groups.

Mangkunegara in Arif (2019) states that organizational culture is a set of assumptions or systems of beliefs, values, and norms developed in organizations that serve as guidelines for behavior for its members to overcome the problem of external and internal adaptation. Organizational culture is a pattern of beliefs and organizational values that are believed and imbued by all members in doing work as an appropriate way to understand, think, and feel about related problems, so that it will become a value or rule within the organization. This will encourage members of the organization to work harder and create work motivation.

Some previous research results show the influence of organizational culture on the quality of accounting information systems. Wisma (2015) research results say that organizational culture influences the quality of accounting information systems. Cultural 
factors become important not only when information systems are created and developed, but must still be considered when information systems are implemented. While Rapina (2014) based on the analysis of research results shows that organizational culture has a significant influence on the quality of accounting information systems. Based on the explanation and results of previous studies above, it can be concluded that that organizational culture influences the quality of accounting information systems. This research model can be seen in Figure 1:

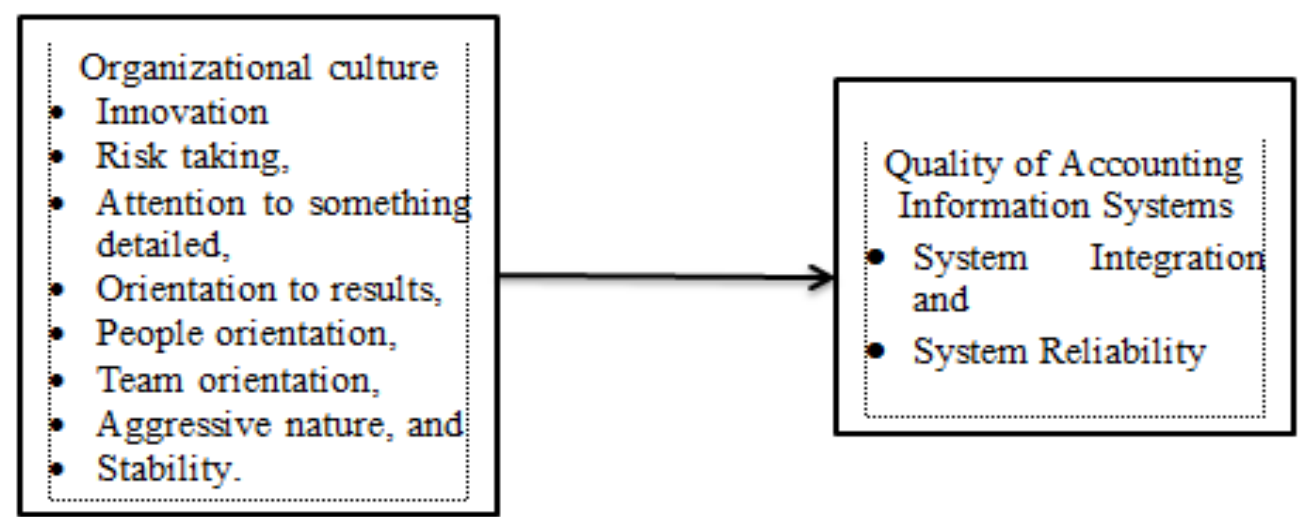

Figure 1. Research Model

Based on the theoretical framework above, the hypothesis to be tested in this study is that organizational culture has a significant effect on the quality of financial accounting information systems.

\section{Research Method}

This research uses descriptive and verification methods. The population in this study was 56 units of the Medan Regional Organization. The sampling technique used is simple random sampling so we get 38 units. Respondents in this study were heads of finance. Data collection techniques in this study used a questionnaire. The question includes two variables: organizational culture (BO) and the quality of the accounting information system (KSIA). Organizational culture variables (BO) consist of 8 indicators, namely: Innovation (BO1), risk taking (BO2), Attention to details (BO3), Results orientation (BO4), People orientation (BO5), Team orientation (BO6), Aggressiveness (BO7) and Stability (BO8). While the accounting information system quality variable (KSIA) consists of 2 (two) dimensions, namely: the integrity of the accounting information system quality (KSIA1) and the reliability of the quality of the accounting information system (KSIA2).

The dimensions of the integrity of the accounting information system quality (KSIA1) consist of 2 (two) indicators, namely: integration between sub-systems (KSIA11) and system integration with other systems (KSIA12). The reliability dimension of the accounting information system (KSIA2) consists of 2 (two) indicators, namely: a system that can work correctly (KSIA21) and a system that can produce accurate information (KSIA22). This study uses a reflective measurement model. The analytical method used is structural equation modeling with a variant-based approach using SMART-PLS, while testing hypotheses using t-test. 


\subsection{Result}

\section{Result and Discussion}

From the results of data processing of organizational culture variables and the quality of accounting information systems with Smart PLS, it can be seen in the following algorithm 1 validity and reliability:

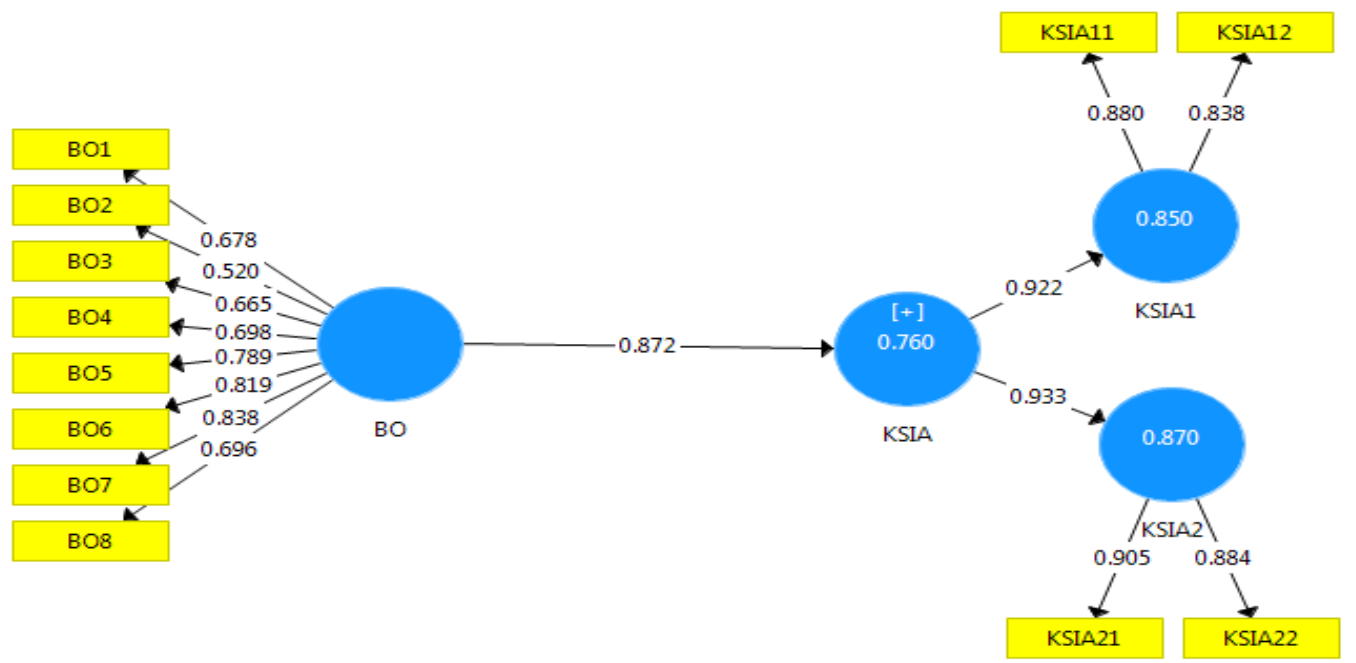

Figure 2. Validity and reliability

Source: Data Processing Results (PLS Algorithm)

Verification results of the validity and reliability of indicators on organizational culture variables and the quality of accounting information systems. Hair et al. (2014: 709) states that the construct has good validity if the Average Variance Extracted value $\geq 0.50$. Furthermore Hair et al. (2010: 710) states that constructs have good reliability is if the value of Construct Reliability $(C R) \geq 0.70$. Verification and reliability results can be seen in Table 4.1 below:

Table 1. Verification and Validity Results

\begin{tabular}{|c|c|c|c|c|c|c|}
\hline Variable & Dimension & Indicator & $A V E$ & $\begin{array}{l}\text { Composite } \\
\text { Reliability }\end{array}$ & Validity & Reliability \\
\hline $\mathrm{BO}$ & & $\begin{array}{l}\mathrm{BO} 1 \\
\mathrm{BO} 2 \\
\mathrm{BO} 3 \\
\mathrm{BO} 4 \\
\mathrm{BO} 5 \\
\mathrm{BO} 6 \\
\mathrm{BO} 7 \\
\mathrm{BO} 8\end{array}$ & 0,517 & 0,894 & Validity & Reliability \\
\hline \multirow[b]{2}{*}{ KSIA } & KSIA1 & $\begin{array}{l}\text { KSIA11 } \\
\text { KSIA12 }\end{array}$ & 0.738 & 0,849 & Validity & Reliability \\
\hline & KSIA2 & $\begin{array}{l}\text { KSIA21 } \\
\text { KSIA22 }\end{array}$ & 0,800 & 0,889 & Validity & Reliability \\
\hline KSIA & & & 0,661 & 0,886 & Validity & Reliability \\
\hline
\end{tabular}


Source: Data Processing Results

The results of outer loading and cross loading can be seen in the following table 4.14:

Table 2. Outer Loadings and Cross Loadings

\begin{tabular}{lllll}
\hline Variabel & BO & KSIA1 & KSIA2 & KSIA \\
\hline BO1 & 0,678 & & & \\
BO2 & 0,520 & & \\
BO3 & 0,665 & & \\
BO4 & 0,698 & & \\
BO5 & 0,789 & & & \\
BO6 & 0,819 & & & \\
BO7 & 0,838 & & & \\
BO8 & 0,696 & & & 0,844 \\
KSIA11 & & 0,880 & 0,735 \\
KSIA12 & & 0,838 & & 0,873 \\
KSIA21 & & & 0,884 & 0,792 \\
KSIA22 & & & & \\
\hline Source: Data Processing Results & & & \\
\hline
\end{tabular}

Source: Data Processing Results

Based on the data in Table 4.1 and Table 4.2 the average variance reflected is above 0.5 and the outer loading indicator in the construct is higher than all cross loading with other constructs, it is concluded that the reflective measurement model is valid. Likewise, based on data from Table 4.1 composite reliability and all outer loading indicators higher than 0.60 , it were concluded that the reflective measurement model was reliable.

\section{Hypothesis Test}

The hypotheses that will be tested in this study are:

Ho: Organizational culture has no significant effect on the quality of accounting information systems.

Ha: Organizational Culture has a significant effect on the quality of accounting information systems.

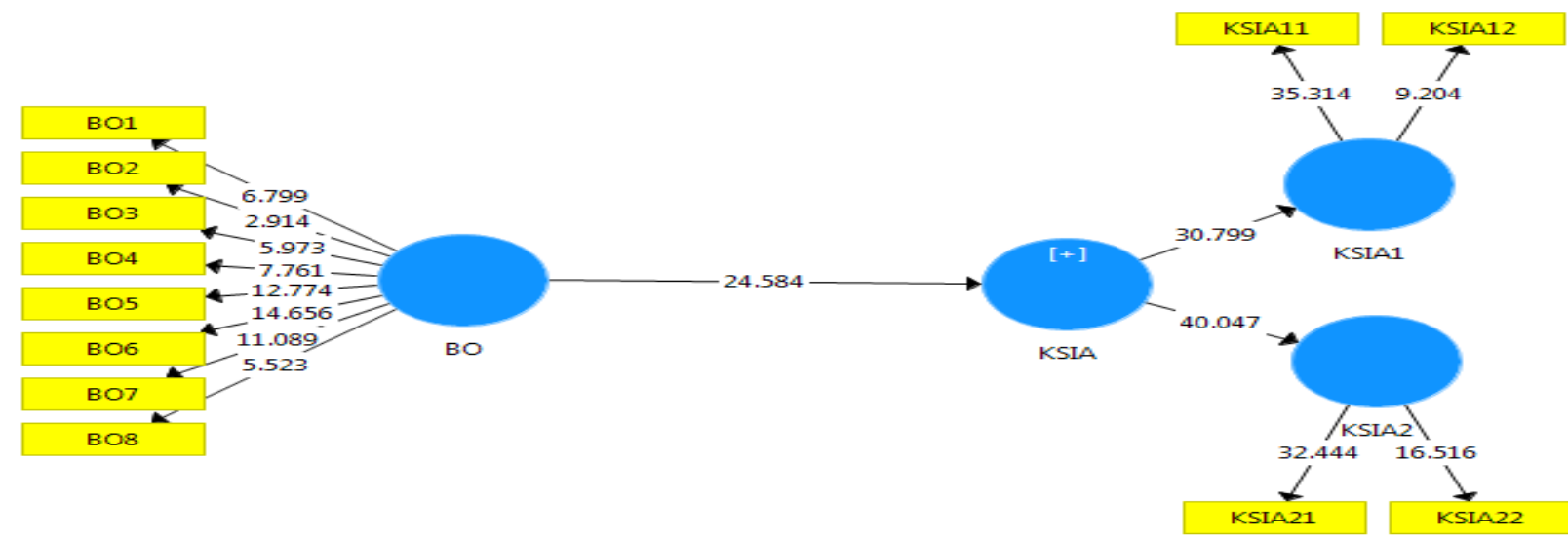

Picture 3. Bootstrapping

Source: Data Processing Results (PLS Bootstrapping) 
Based on the data in Figure 4.2, the researchers found that t-Statistic is greater than tTable (24,584>1.69). This means that Ho is rejected or in other words, organizational culture significantly influences the quality of accounting information systems. The path coefficient between top management support and the quality of financial accounting information systems is 0.872 ; the coefficient of determination (R2) is 0.760 . This means that organizational culture is able to explain the quality of accounting information systems by $76 \%$, while the remaining $24 \%$ explains other factors not included in this research model.

\subsection{Discussion}

Based on the results of hypothesis testing, we find empirical evidence in the context of the organization of terrain city area organizations that organizational culture has a significant effect on the quality of accounting information systems. The results of this study provide empirical evidence that the better the organizational culture, the more appropriate and clear directions and guidelines for each member, the more the quality of the accounting information system increases. In other words the quality of the accounting information system will improve if the culture of the organization gets better.

The results of this study confirm the theory put forward by various experts. Organizational culture is an important factor in information systems (Leidner and Kayworth, 2006). The use of information systems must be built with a clear understanding of culture (Laudon and Laudon, 2012: 94). Ahuja and Thatcher (2014) say that cultural aspects can optimize the use of information systems in innovation. Culture is important not only when information systems are created and developed, but must also be considered when information systems are implemented (Wisma, 2015).

Empirical evidence about organizational culture influences the quality of accounting information systems, in line with the results of previous studies such as: Endraria (2018), Budi (2015), Wisma (2015), Rapina (2014), Ahuja and Thatcher (2014), Leidner and Kayworth ( 2006).

\section{Conclusions}

Based on the results of hypothesis testing and discussion of the research results, it was concluded that: organizational culture variables significantly influence the quality of accounting information systems in the Regional Organization of Medan City.

\section{References}

Ahuja, Manju K, and Jason Bennett Thatcher. (2014). "Moving Beyond Intentions and Toward Theory of Trying : Effects of Work Environment and Gender on Post Adoption Information Technology Use." 29(3): 427-59.

Arif, S. (2019). Influence of Leadership, Organizational Culture, Work Motivation, and Job Satisfaction of Performance Principles of Senior High School in Medan City. Budapest International Research and Critics Institute (BIRCI-Journal), 239-254.

Baltzan, Paige. (2014). Business Driven Information Systems. Fourth Edi. Americas, New York: McGraw-Hill/Irwin.

Budi, Inta Setya Nusa. (2015). "Influence Of Organizational Culture And Structure On Quality Of Accounting Information System.” 4(5). 
Darma, Jufri, Azhar Susanto, Sri Mulyani, and Jadi Suprijadi. (2018). "The Role of Top Management Support in the Quality of Financial Accounting Information Systems." Journal of Applied Economic Sciences XIII(4): 1008-19.

Endraria. (2018). "The Effect Of Organizational Culture And Discipline On Quality Of Accounting Information System In The Financial Management Agency And Asset Regional Government Of Regency Of Regency , City And West Java Province." 7(4): 73-77.

Fitrios, Ruhul, Azhar Susanto, Roebiandini Soemantri, and Harry Suharman. (2018). "The Influence Of Environmental Uncertainty On The Accounting Information System Quality And Its Impact On The Accounting Information." Journal of Theoretical and Applied Information Technology 96(21): 7164-75.

Hair, Joseph F., G. Tomas M. Hult, Christian M. Ringle, and Marko Sarstedt. (2014). A Primer On Partikal Least Squares Structural Equation Modeling (PLS-SEM). Los Angeles: SAGE Publications, Inc.

Hair, J.F., Black, W.J., Babin, B.J., \& Anderson, R.E. (2010). Multivariate data analysis. Englewood Cliff, NJ: Prentice Hall.

Hutajulu, Sarma. (2017). http://harian.analisadaily.com/kota/news/banyak-website skpdpemprovsu-bermasalah/302921/2017/01/20. Diakses:24/07/2019

Ladan, Shamsudeen Shagari, Akilah Abdullah, and Rafeah Mat Saat. (2017). "Accounting Information Systems Effectiveness: Evidence From The Nigerian Banking Sector." interdisciplinary journal of information, knowledge, and management 12: 309-35.

Laudon, Kenneth C., and Jane P. Laudon. (2012). 7 Revista de Administração Contemporânea Management Information Systems: Managing the Digital Firm. Twelfth Ed. United States of America: Pearson Education, Inc.

Leidner, Dorothy E, and Timothy Kayworth. (2006). "A Review Of Culture In Information Systems Research: Toward A Theory Of Information Technology Culture Conflict." 30(2): 357-99.

McShane, Steven L, mary Ann Von Glinow, and Radha R. Sharma. (2008). Organizational Behavior. Fourth Edi. New York: McGraw-Hill Companies, Inc.

Ong, Chorng-shyong, Min-yuh Day, and Wen-lian Hsu. (2009). "The Measurement of User Satisfaction with Question Answering Systems." Information \& Management 46(50): $397-403$.

Rapina. (2014). "Factors Influencing the Quality of Accounting Information System and Its Implications on the Quality of Accounting Information." Research Journal of Finance and Accounting 5(2): 148-54.

Robbins, Stephen P., and Timothy A. Judge. (2013). Organizational Behavior. 15th ed. United States of America: Pearson Education.

Romney, Marshall B, and Paul John Steinbart. (2018). Accounting Information Systems. Fourteenth. New York: Pearson.

Samuel, Nzomo. (2013). "Impact of Accounting Information Systems on Organizational Effectiveness of Automobile Companies in Kenya." University Of Nairobi (November).

Satzinger, John W., Robert B. Jackson, and Stephen D. Burd. (2009). SYSTEMS Analysis And Design In A Changing World. Fifth Edit. USA: Course Technology.

Stair, Ralph M., and George W. Reynolds. (2010). Principles of Information Systems A Managerial Approach. Ninth Edit. United States of America: Course Technology. 
Turner, Leslie, Andrea Weickgenannt, and Mary Kay Copeland. (2017). Accounting Information Systems: Control and Processes. Third Edit. United States of America: WILEY.

Wisna, Nelsi. (2015). "Organizational Culture and Its Impact On The Quality Of Accounting Information Systems.” 82(2): 266-72. 